\title{
DISPLACEMENT OF THYROXINE FROM HUMAN THYROXINE- BINDING GLOBULIN BY ANALOGUES OF HYDANTOIN. STERIC ASPECTS OF THE THYROXINE-BINDING SITE *
}

\author{
By JACK H. OPPENHEIMER † AND RICHARD R. TAVERNETTI
}

(From the Endocrine Service, Medical Division, Montefiore Hospital, New York, N. Y.)

(Submitted for publication July 13, 1962 ; accepted August 22, 1962)

Administration of the anticonvulsant 5,5-diphenylhydantoin sodium (DPH, Dilantin) depresses the level of serum protein-bound iodine (PBI) without inducing clinical hypothyroidism or changing other measures of thyroid function, such as 24-hour thyroidal accumulation of $\mathrm{I}^{131}$, thyroidal clearance of $\mathrm{I}^{131}$, serum cholesterol, and basal metabolic rate (1). Since DPH also induces a fall in the serum PBI of hypothyroid and hypopituitary patients maintained on a constant exogenous dose of dessicated thyroid, the action of DPH must be largely extrathyroidal. DPH has also been shown to interfere with the binding of thyroxine $\left(\mathrm{T}_{4}\right)$ by plasma proteins, as measured by the increased uptake of $\mathrm{I}^{131} \mathrm{~L}$-triiodothyronine $\left(\mathrm{T}_{3}-\mathrm{I}^{131}\right)$ and $\mathrm{I}^{131} \mathrm{~L}$-thyroxine $\left(\mathrm{T}_{4}-\mathrm{I}^{131}\right)$ by red cells $(1,2)$, as well as by the increased dialysis of $\mathrm{T}_{4}$ across a semipermeable membrane after the addition of $\mathrm{DPH}$ to serum (2). It appears probable that fall in circulating PBI is due to this inhibition of protein-binding.

Electrophoretic studies $(2,3)$ have indicated that $\mathrm{DPH}$ appears to interfere with the binding, specifically, of the alpha globulin carrier of $\mathrm{T}_{4}$, thyroxine-binding globulin (TBG). In vitro addition of DPH causes a displacement of $\mathrm{T}_{4}$ from alpha globulin to prealbumin and albumin. The present studies were undertaken to determine 1) the reversibility and specificity of the interaction between $\mathrm{DPH}$ and $\mathrm{T}_{4}$ at the alpha globulin binding site and 2) the structural requirements of the $\mathrm{DPH}$ molecule necessary for this phenomenon.

\section{METHODS}

The radiochromatographic purity of each shipment of $\mathrm{T}_{4}-\mathrm{I}^{131}$ in 50 per cent propylene glycol ${ }^{1}$ was checked in a

* Supported by U. S. Public Health Service Grant B3000, National Institutes of Health, Bethesda, Md. $\dagger$ Investigator, Health Research Council of New York City.

1 Abbott Laboratories, North Chicago, Ill. descending butanol : dioxane: $2 \mathrm{~N} \mathrm{NH}_{4} \mathrm{OH}(4: 1: 5)$ system. Carrier iodide, $T_{4}$, and $T_{3}$ were added. Distribution of radioactivity was determined as described below. The carrier thyronines were then located by visual inspection under a short-wave ultraviolet lamp, and iodide was identified by a palladium chloride stain. All samples were shown to have less than 10 per cent contamination with $I^{131}$. Radioactive $T_{4}$ was added to serum or plasma to enhance the endogenous concentration of stable thyroxine by $3 \mu \mathrm{g}$ per $100 \mathrm{ml}$. Equilibration between endogenous and exogenous thyroxine was carried out for at least 30 minutes. 5,5-Diphenylhydantoin- $4 \mathrm{C}^{14}$ with specific activity of $0.96 \mathrm{mc}$ per mmole was used. ${ }^{2}$

Nonradioactive hydantoin analogues used were: 5,5diphenylhydantoin (as Dilantin sodium),3, 4 Mesantoin, ${ }^{5}$ Peganone, ${ }^{1,} 6$ A 16401,1, 6 A 11164,1, 6 A 366,1, 6 A 1472,1, 6 A 4015,1, 6 A 7660,1, 6 PD 6 through $9^{3}$ (see Table III for these 13 compounds), PD 10 through 14,3 A 11106,1, 6 $\mathrm{A}(\mathrm{N} 1)_{1,1,6} \mathrm{~A}(\mathrm{~N} 3)_{1,1,6}$ and $\mathrm{A}(\mathrm{N} 1,3)^{1,6}$ (see Table IV for these 9). All analogues were dissolved in ethanol and added to plasma or serum for electrophoretic studies in a volume less than 5 per cent of the total volume of the mixture. In each instance, a comparable volume of ethanol was added to control samples of plasma or serum. The addition of ethanol in these quantities did not affect the binding of thyroxine by the various plasma proteins.

Since the distribution of $T_{4}-I^{131}$ was similar in plasma and serum, both were suitable for the electrophoretic studies. Compounds listed in Table III were added to sera of euthyroid subjects, and those in Table IV were added to samples of a single lot of reconstituted lyophilized plasma with PBI $4.5 \mu \mathrm{g}$ per $100 \mathrm{ml}^{7}$ This plasma was also used in experiments summarized in Table $I$ and Figure 1. Another lot of lyophilized plasma, with PBI $7.3 \mu \mathrm{g}$ per $100 \mathrm{ml}$, was used in the experiment indicated in Table II.

Electrophoresis of the serum proteins was performed

2 Kindly supplied by Los Alamos Scientific Laboratory, University of California, courtesy of Dr. Wright $\mathrm{H}$. Langham.

${ }^{3}$ Parke, Davis \& Company, Ann Arbor, Mich.

${ }^{4}$ Courtesy of Dr. R. W. Flemming.

${ }^{5}$ Sandoz Pharmaceuticals, Hanover, N. J., courtesy of Dr. Sidney Gimpel.

${ }^{6}$ Courtesy of Dr. J. W. Close, who also supervised the synthesis of $A(N 1), A(N 3)$, and $A(N 1,3)$.

${ }^{7}$ Travenol Laboratories, Morton Grove, Ill. 
in a Durrum-type electrophoretic cell (Spinco). Serum, $0.010 \mathrm{ml}$, was applied to each paper strip. A glycine acetate buffer of ionic strength 0.15 and $\mathrm{pH} 8.6$ (4) was used. A constant current of 10 ma per cell was applied for the 16 hours of electrophoresis. After completion of electrophoresis, the strips were dried, assayed for radioactivity, and then stained for protein with bromphenol blue.

Distribution of $\mathrm{T}_{4}-\mathrm{I}^{131}$ along the paper strips was measured by a gas flow meter (Nuclear-Chicago, model D 47) with a thin mica end-window and a continuously recording rate meter (Nuclear-Chicago, model 1620B) connected to a rectilinear writer (Texas Instruments, model R 1000). Areas under the resulting curve were measured graphically by tracing the record on finely calibrated rectilinear graph paper and determining the number of squares subtended by the curve. This method of estimating areas was found to be more reliable in our hands than the use of the planimeter. The average percentage of $T_{4}-{ }^{131}$ associated with alpha globulin in eight replicate samples of the same serum subjected simultaneously to electrophoresis was 66.4 , with one standard deviation of 1.9 percentage points.

Gamma-ray counting of various liquid and solid samples was performed in a well-type scintillation detector connected to a spectrometer (Packard Autogamma, series $410 \mathrm{~A}$ ).

Plasma samples containing $\mathrm{DPH}-\mathrm{C}^{14}$ were counted as follows: $0.1 \mathrm{ml}$ serum was added to vials containing 17 $\mathrm{ml}$ of a phosphor (PPO-POPOP) in toluene, and the resulting precipitate was allowed to settle in the refrigerator unit of a Tricarb liquid scintillation spectrometer (Packard Instruments Corp.). Serial counts were obtained on individual samples until a stable counting rate was obtained.

Total plasma protein determinations were performed by the biuret reaction (5).

Dialysis of $T_{4}$ (Figure 1) was carried out as follows. $\mathrm{T}_{4}-\mathrm{I}^{131}$ was added to plasma in quantities sufficient to raise the level of endogenous $\mathrm{T}_{4}$ by $3 \mu \mathrm{g}$ per $100 \mathrm{ml}$. Twotenths $\mathrm{ml}$ of this plasma was then diluted with $4.8 \mathrm{ml}$ phosphate buffer of ionic strength 0.17 and $\mathrm{pH} 7.4$, added to the inside of a cellophane bag previously treated with

TABLE I

Effect of prolonged dialysis of plasma containing $7.28 \times 10^{-4}$ $M$ 5,5-diphenylhydantoin on the percentage of thyroxine $I^{131}$ bound to thyroxine-binding globulin*

\begin{tabular}{clccc}
\hline Time & & $\begin{array}{c}\% \text { odded } \\
\mathrm{T}_{4-I^{131}} \\
\text { remaining } \\
\text { in dialy- } \\
\text { sis bag }\end{array}$ & $\begin{array}{c}\text { \% added } \\
\text { DPH-4C14 } \\
\text { remaining } \\
\text { in dialy- } \\
\text { sis bag }\end{array}$ & $\begin{array}{c}\% \\
\mathrm{~T}_{4-I^{131}} \\
\text { bound } \\
\text { to TBG }\end{array}$ \\
\hline hours & Control & 100 & & 59.3 \\
0 & DPH & 100 & 100 & 29.3 \\
& Control & 92 & & 62.5 \\
& DPH & 89 & 10.5 & 56.4
\end{tabular}

*Abbreviations: $\quad \mathrm{T}_{1-I^{131}}=\mathrm{I}^{131}-\mathrm{L}-$ thyroxine, $\quad \mathrm{DPH}-4 \mathrm{C}^{14}=\mathrm{C}^{14}-5,5$ diphenylhydantoin sodium, and TBG=thyroxine-binding globulin. nitric acid (6), and dialyzed against $15 \mathrm{ml}$ phosphate buffer in a Lusteroid centrifuge tube (6) for 16 hours at $37.5^{\circ} \mathrm{C}$ on a rotating platform kept in a bacterial incubator.

In order to separate radioactive thyroxine from contaminating iodide- $\mathrm{I}^{131}$, the serum-precipitable $\mathrm{I}^{131}$ both inside and outside the bag was determined. To $2-\mathrm{ml}$ samples from inside and 5-ml samples from outside the bags, equal volumes of outdated blood bank plasma were added. Protein was precipitated with 20 per cent trichloracetic acid and washed twice with 1 per cent trichloracetic acid. It was assumed that the serum-precipitabtle $\mathrm{I}^{131}$ represented thyroxine. The percentage of thyroxine dialyzed across the membrane in 16 hours was determined by the equation

$$
T=\frac{V_{0} \times S P I_{0}{ }^{131}}{\left(V_{1} \times S P I_{i}^{131}\right)+\left(V_{0} \times S P I_{0}{ }^{131}\right)}
$$

where $T=$ per cent $\mathrm{T}_{4}-\mathrm{I}^{131}$ dialyzed in 16 hours, $S P I_{0}{ }^{131}=$ serum-precipitable $\mathrm{I}^{131}$ outside bag per $\mathrm{ml}, S P I_{i}{ }^{131}=$ seru:nprecipitable $\mathrm{I}^{131}$ inside bag per $\mathrm{ml}, V_{o}=$ total volume outside bag $(15 \mathrm{ml})$, and $V_{i}=$ total volume inside bag $(5$ $\mathrm{ml})$.

EXPERIMENTAL PROCEDURES AND RESULTS

\section{Demonstration of competitive binding between} $D P H$ and $T_{4}$ at $T B G$

Reversibility of DPH effect by prolonged dialysis. In order to determine whether the DPH-induced depression of alpha globulin binding of $\mathrm{T}_{4}$ could be reversed by prolonged dialysis, the following experiment was performed. Three lots of plasma were prepared: 1) plasma with $\mathrm{T}_{4}-\mathrm{I}^{131}$ added to increase the $T_{4}$ concentration by $3 \mu \mathrm{g}$ per $100 \mathrm{ml}, 2$ ) plasma plus $3 \mu \mathrm{g}$ per $100 \mathrm{ml} \mathrm{T}{ }_{4}-\mathrm{I}^{131}$ plus $7.28 \times 10^{-4} \mathrm{M}$ stable $\mathrm{DPH}$, and 3) plasma plus $7.28 \times 10^{-4} \mathrm{M} \mathrm{DPH}-4 \mathrm{C}^{14}$, made up to specific ac tivity $0.096 \mathrm{mc}$ per mmole. Samples from each lot were set aside at $5^{\circ} \mathrm{C}$ until the completion of the dialysis experiment. Also, $5 \mathrm{ml}$ of each lot of plasma was dialyzed in a cellophane bag against 3 changes of $1,000 \mathrm{ml}$ isotonic saline for 48 hours at $5^{\circ} \mathrm{C}$ with constant agitation. The concentrations of total protein, $\mathrm{T}_{4}-\mathrm{I}^{131}$, and $\mathrm{DPH}$ $4 \mathrm{C}^{\mathbf{1 4}}$ before and after dialysis were determined. The percentages of the original quantity of $\mathrm{T}_{4}$ and $\mathrm{DPH}$ in each dialysis bag at the end of the experiment were calculated on the basis of the radioactive measurements and the change in total protein concentrations, and the electrophoretic distribution of $\mathrm{T}_{4}-\mathrm{I}^{131}$ among the plasma protein fractions was determined before and after dialysis.

The results of this experiment are indicated in Table I. It is evident 1 ) that dialysis removed ap- 
TABLE II

Effect of increasing concentrations of L-thyroxine on displacement of L-thyroxine by $\left(7.28 \times 10^{-4} \mathrm{M}\right)$ diphenylhydantoin*

\begin{tabular}{|c|c|c|c|c|c|}
\hline \multirow{2}{*}{$\begin{array}{l}\text { Concentration } \\
\text { of L-thyroxine* }\end{array}$} & \multirow{2}{*}{$\begin{array}{l}\text { Concentration } \\
\text { of DPH }\end{array}$} & \multicolumn{3}{|c|}{ Distribution of $T_{4-I^{131}}$} & \multirow{2}{*}{$\begin{array}{l}\text { Concentration } \\
\text { of } L \text {-thyroxine } \\
\text { in } \alpha \text { globulin }\end{array}$} \\
\hline & & $\alpha$ Globulin & Albumin & Prealbumin & \\
\hline \multirow[t]{2}{*}{$\times 10^{-7} \mathrm{M}$} & $\times 10^{-4} \mathrm{M}$ & $\%$ & $\%$ & $\%$ & $\times 10^{-7} \mathrm{M}$ \\
\hline & 0 & 57.3 & 10.0 & 32.7 & 1.05 \\
\hline \multirow{2}{*}{1.83} & 7.28 & 26.3 & 13.6 & 59.8 & 0.48 \\
\hline & 0 & 35.5 & 12.4 & 52.1 & 2.93 \\
\hline \multirow{2}{*}{8.25} & 7.28 & 24.6 & 13.9 & 61.5 & 2.03 \\
\hline & 0 & 19.8 & 17.9 & 62.3 & 2.91 \\
\hline \multirow{2}{*}{14.7} & 7.28 & 20.1 & 14.3 & 65.6 & 2.95 \\
\hline & 0 & 11.4 & 21.1 & 67.5 & 3.15 \\
\hline 27.6 & 7.28 & 11.6 & 20.0 & 68.4 & 3.20 \\
\hline
\end{tabular}

* Estimated by assuming that serum protein-bound iodine is due entirely to thyroxine content of serum. Abbreviations: DPH $=$ diphenylhydantoin; $T_{4}-I^{131}=$ thryoxine $I^{131}$. Data previously presented (2).

proximately 90 per cent of DPH from plasma but only approximately 10 per cent of $T_{4}$, and 2) that with the removal of $\mathrm{DPH}$, the binding of $\mathrm{T}_{4}$ by alpha globulin returned to a nearly normal value. The residual depression of $\mathrm{T}_{4}$ binding to alpha globulin can be attributed to the small fraction (10 per cent) of the DPH not dialyzed out of the bag. A separate experiment showed that the addition of $7.28 \times 10^{-5} \mathrm{M} \mathrm{DPH}$, the approximate concentration of residual DPH, to plasma diluted with saline for a final protein concentration like that of plasma after dialysis depresses the amount of $\mathrm{T}_{4}-\mathrm{I}^{131}$ bound to alpha globulin from 62.2 to 57.1 per cent. This depression was comparable to that observed at the conclusion of dialysis. It can also be seen from Table I that the concentration of $\mathrm{T}_{4}-\mathrm{I}^{131}$ in the bag containing $\mathrm{DPH}$ was 3.3 per cent less than that in the control sample after dialysis. This difference could have been due either to experimental error or to the effect of $\mathrm{DPH}$ in accelerating $\mathrm{T}_{4}$ dialysis (2). In either event, this discrepancy is too small to account for the reversibility of DPH effect.

Specificity of the interaction between DPH and $T_{4}$ at the alpha globulin binding site. Not only can the DPH effect be reversed by dialysis of plasma against saline, it can also be abolished by the addition of an excess of stable $\mathrm{T}_{4}$ to the plasma (Table II). The same maximal binding capacity of TBG, $3.1 \times 10^{-\tau} \mathrm{M}$, is attained by the addition of increasing concentrations of $\mathrm{T}_{4}$ both in the presence and in the absence of $7.28 \times 10^{-4} \mathrm{M}$
$\mathrm{DPH}$, and falls well within previously published ranges of normal human sera $(7,8)$. This similarity in maximal binding capacity suggests that high concentrations of $\mathrm{T}_{4}$ can displace $\mathrm{DPH}$ previously bound to TBG.

The results of these experiments indicate that $\mathrm{DPH}$ and $\mathrm{T}_{4}$ bind competitively and reversibly to the same alpha globulin site.

\section{Displacement of $T_{4}$ from $T B G$ by analogues of hydantoin}

The demonstration of competitive binding between DPH and $T_{4}$ suggests the possibility of some structural analogy between these compounds. In an effort to explore this hypothesis, a number of hydantoin analogues were tested for their ability to displace $T_{4}$ from TBG. In the initial phase of these studies, individual substances were screened by addition of the test compound to serum or plasma in a concentration of $7.28 \times 10^{-4} \mathrm{M}$. A compound was not considered to have any significant activity if it failed to depress the percentage of $\mathrm{T}_{4}$ bound to TBG by more than 5 percentage points. Table III lists those compounds found to be inactive. Because the test substance might be washed off the paper during electrophoresis, hydantoin, Mesantoin, and Peganone were also added to the buffer in a concentration of $7.28 \times 10^{-4} \mathrm{M}$. No depression of $\mathrm{T}_{4}-\mathrm{I}^{131}$ in the alpha globulin area was observed. A 11164 and A 1472 were also added to the plasma in a concentration of $15.6 \times$ 
$10^{-4} \mathrm{M}$, and again no effect was observed. All hydantoins failing to displace $\mathrm{T}_{4}-\mathrm{I}^{131}$ from $\mathrm{TBG}$ (Table III) lacked a diphenyl group at 5-C. The addition, however, of $7.28 \times 10^{-4} \mathrm{M}$ diphenyl ether dissolved in ethanol had no effect on the distribution of $\mathrm{T}_{4}-\mathrm{I}^{131}$.

Table IV lists those compounds effective in displacing $\mathrm{T}_{4}$ from TBG. All test compounds were added to the standard lot of reconstituted lyophilized plasma in a concentration of $7.28 \times 10^{-4} \mathrm{M}$. Four electrophoretic strips of the test substance and at least two of the control plasma and two of plasma containing $7.28 \times 10^{-4} \mathrm{M} \mathrm{DPH}$ were used in each run. All control values as well as those obtained for plasma containing DPH were pooled, since there was no significant variation in separate runs. The activity of each test compound in displacing $\mathrm{T}_{4}$ from $\mathrm{TBG}$ relative to $\mathrm{DPH}$ was expressed as $A=100(C-X) / C-D$, where $A=$ relative activity, $C=$ per cent $\mathrm{T}_{4}-\mathrm{I}^{131}$ bound to TBG in control plasma, $X=$ per cent $\mathrm{T}_{4}-\mathrm{I}^{131}$ bound to TBG in plasma containing $7.28 \times 10^{-4} \mathrm{M}$ test substance, and $D=$ per cent $\mathrm{T}_{4}-\mathrm{I}^{131}$ bound to TBG in plasma containing $7.28 \times 10^{-4} \mathrm{M} \mathrm{DPH}$.

TABLE III

Hydantoins failing to displace L-thyroxine from alpha globulin*

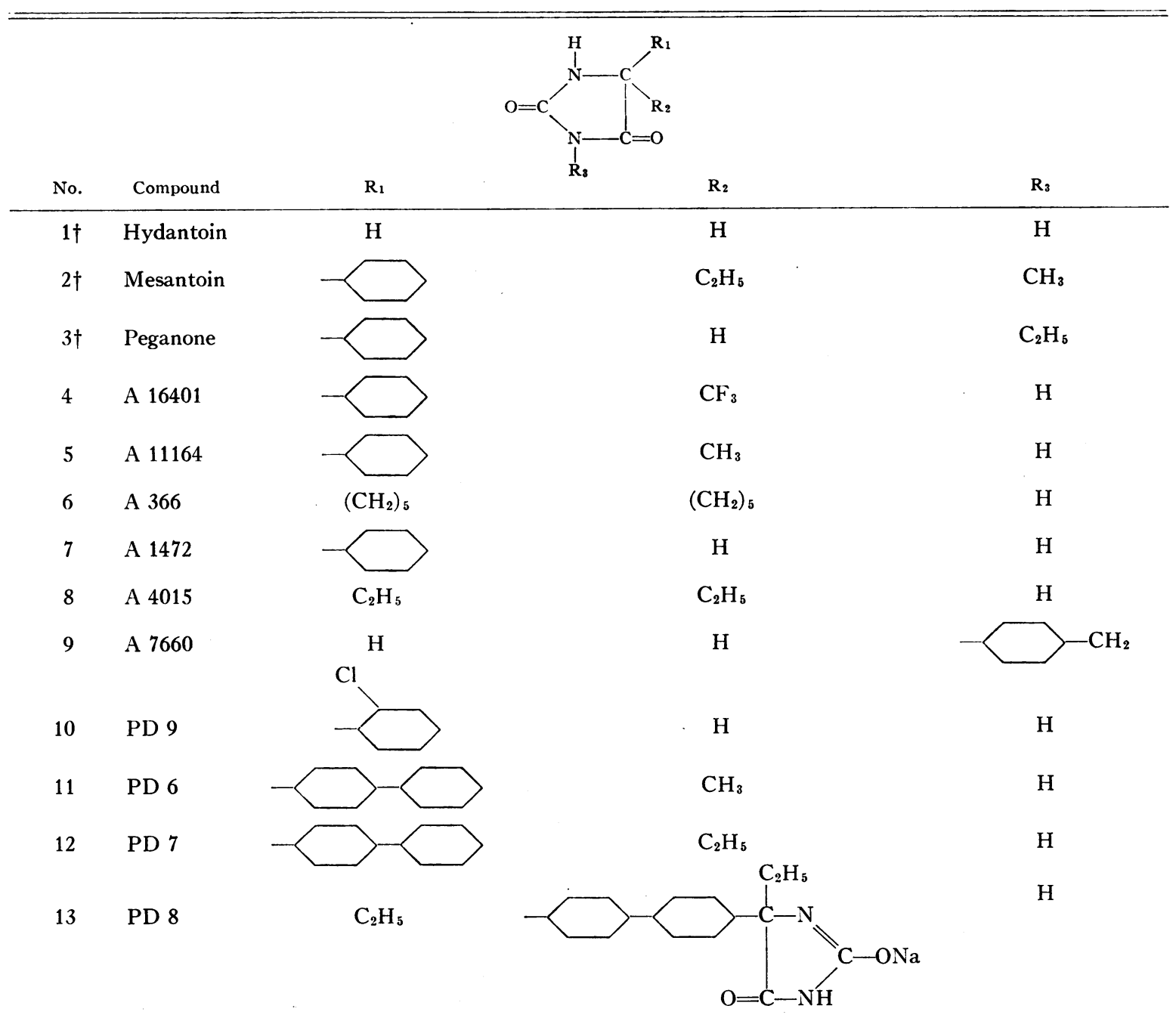

* All compound with different $\mathrm{R}_{1}$ and $\mathrm{R}_{2}$ substituents are racemic mixtures of the optically active compounds. All were added to serum in a concentration of $7.28 \times 10^{-4} \mathrm{M}$. Hexagonal figures without double bars represent benzene rings.

$\dagger$ Compounds added to buffer as well as to serum in a concentration of $7.28 \times 10^{-4} \mathrm{M}$. 
TABLE IV

Hydantoins displacing L-thyroxine from alpha globulin*

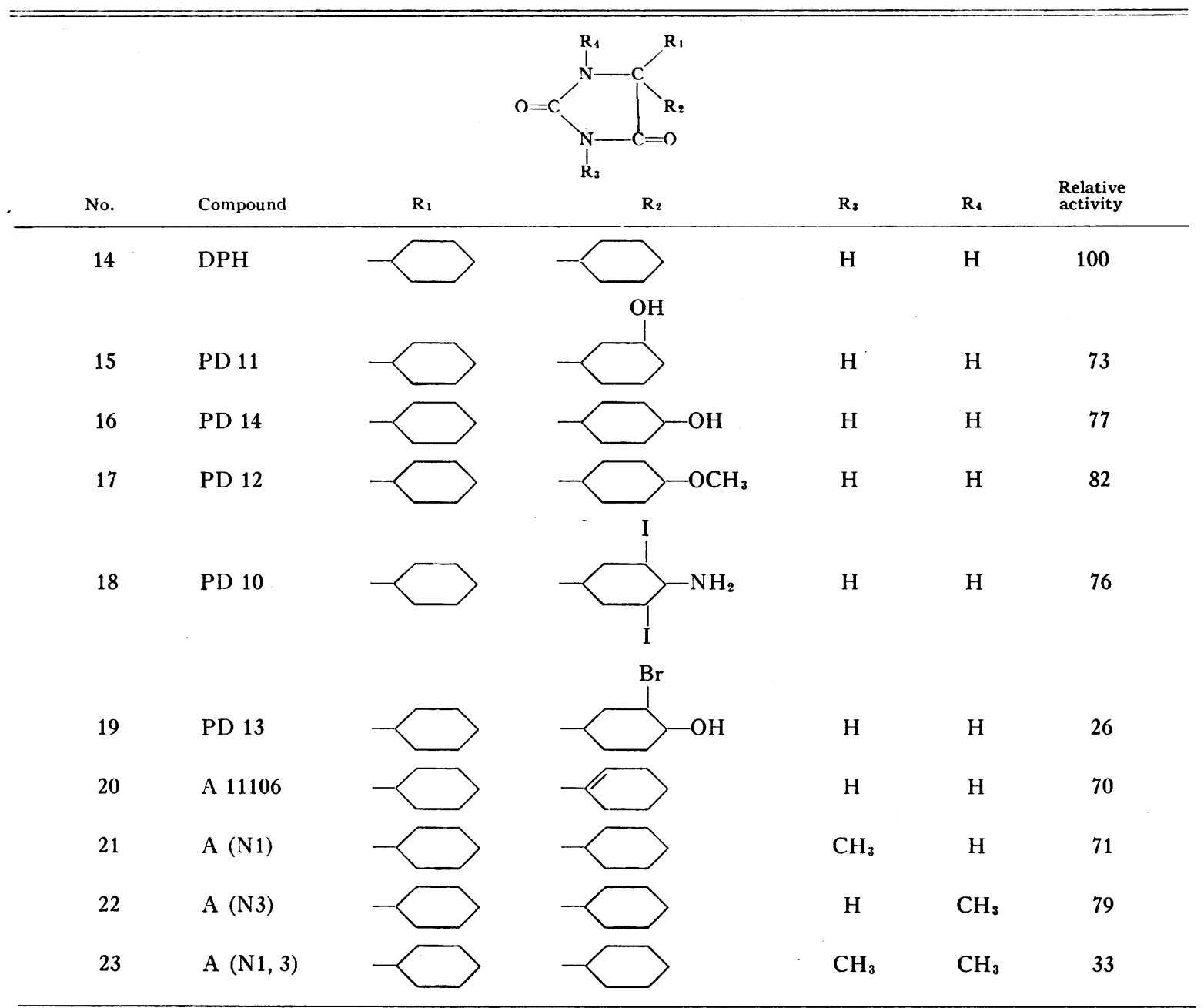

${ }^{*}$ All compounds with different $\mathrm{R}_{1}$ and $\mathrm{R}_{2}$ substituents are mixtures of the optically active varieties. Relative activity defined in text. Hexagonal figures without double bars represent benzene rings. DPH $=5,5$-diphenylhydantoin sodium.

All of the effective compounds (Table IV) possessed a diphenyl linkage at 5-C, with the exception of A 11106, which had one phenyl and one cyclohexene group. Also, all compounds in this series had a displacement activity less than that of $\mathrm{DPH}$, i.e., a relative activity less than 100 . While most had values between 70 and 82, PD 13 and $A(N 1,3)$ had considerably lesser degrees of activity.

Because of the possible importance of the diphenyl grouping, $\left(7.28 \times 10^{-4} \mathrm{M}\right)$ 5,5-diphenylbarbituric acid ${ }^{5}$ was tested in the same fashion as the effective hydantoins and was also able to displace $T_{4}$ from TBG, with a relative activity of 43 .
The possibility that $\mathrm{DPH}$ effects a redistribution of $\mathrm{T}_{4}-\mathrm{I}^{131}$ by increasing binding of albumin and prealbumin rather than by decreasing available binding sites on alpha globulin was considered in a previous study (2) and was rejected, since DPH increased dialysis of $\mathrm{T}_{4}-\mathrm{I}^{131}$ through a semipermeable membrane from a compartment of diluted serum to a surrounding compartment of aqueous buffer. A similar dialysis experiment with $\mathrm{DPH}$, hydantoin, and $A(N 1,3)$ is summarized in Figure 1. Hydantoin, which failed to displace $T_{4}$ in the electrophoretic studies, also failed to increase dialysis of $\mathrm{T}_{4}$ through the cellophane bag. A (N1), on the other hand, did increase it though to a 


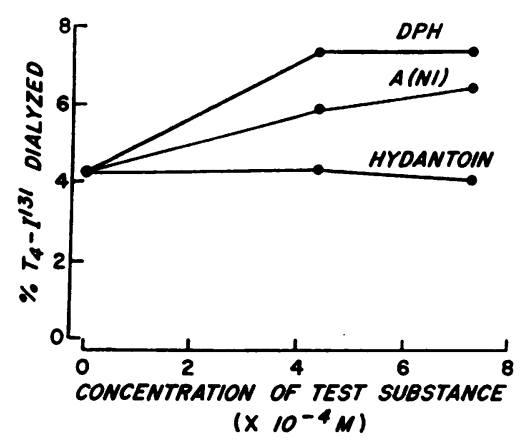

Fig. 1. EFFECT OF THREE HYDANTOINS ON THE DIALYSIS of $\mathrm{T}_{4}-\mathrm{I}^{131}$ ACROSS A Cellophane Membrane. Concentration of test substance refers to initial concentration of test substance inside bag. $\mathrm{DPH}=$ diphenylhydantoin; for A(N1), see Table IV.

lesser extent than DPH. These results were thus entirely analogous to those of the electrophoretic studies and again demonstrated that the effective hydantoins reduced the total number of $T_{4}$ plasma binding sites.

\section{DISCUSSION}

The relative specificity of TBG is well established (9-11). The demonstration that DPH and $\mathrm{T}_{4}$ bind competitively for this trace protein suggests the possibility of a structural analogy be- tween these compounds. Although conventional two-dimensional representations give no clear indications of such an analogy, three-dimensional models suggest that the two molecules may resemble each other in the diphenyl-ether linkage of $\mathrm{T}_{4}$ and the diphenyl group at $5-\mathrm{C}$ of $\mathrm{DPH}$, as illustrated in Figure $2 .^{8}$ This representation is based on known interatomic distances and bond angles (12).

The proposed analogy rests on the following considerations. The angle between the two valence bonds of oxygen at the ether linkage of $\mathrm{T}_{4}$ is approximately $110^{\circ}$, and corresponds closely to the angle of $109^{\circ} 28^{\prime}$ between the carbon bonds connecting the phenyl rings of DPH. The distance between the ether oxygen of $\mathrm{T}_{4}$ and the phenyl ring is $1.36 \AA$, whereas the corresponding distance between 5-C and the phenyl ring of $\mathrm{DPH}$ is $1.46 \AA$, but the difference between these distances ought not to prevent binding of both substances on a complementary configuration on the protein receptor site. In Figure 2, the phenyl groups of $T_{4}$ are not drawn perpendicular to the plane of the paper, since the large iodine substituents on 3-C and 5-C probably induce the phenyl

\footnotetext{
${ }^{8}$ Drawn with the help of Breiden Stereomodels, Swissco Instruments, Greenville, IIl.
}

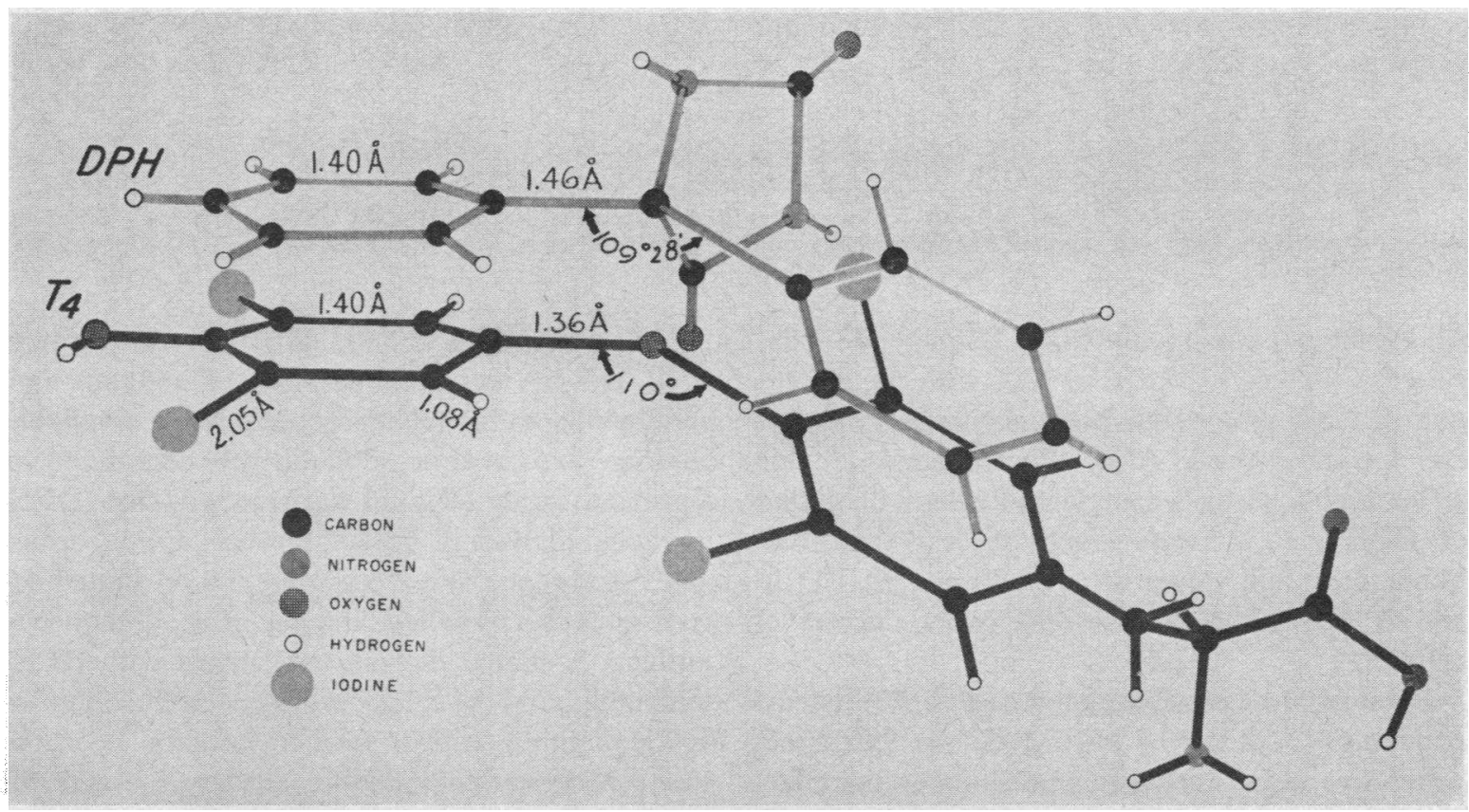

Fig. 2. Three-dimensional Representation of the proposed Steric analogy Between L-thyroxine (T4) AND 5,5-DIPHENYLHYDANTOIN (DPH). 
groups to be in angular relation to each other. It appears likely, however, that the phenyl groupings at 5-C of $\mathrm{DPH}$ rotate freely on their longitudinal axes and can assume a spatial position analogous to that of the phenyl groups of $T_{4}$ on the protein-receptor surface.

Results of the present studies on hydantoin analogues support this hypothesis. All hydantoin analogues (Tables III and IV) with a diphenyl group at 5-C had measurable activity in displacing $\mathrm{T}_{4}$ from $\mathrm{TBG}$, whereas those without this group, with one exception, were inactive. The exception, A 11106, has one phenyl and one cyclohexene group at 5-C, and the configuration of the cyclohexene group may resemble the phenyl structure sufficiently to allow displacement from TBG. If this compound is found, like DPH, competitively to displace $T_{4}$ from TBG, the importance of the internal resonance of the phenyl groups as factor in the competition would also be minimized. Further studies, with saturated and partly saturated six-membered rings at 5-C, appear indicated.

All hydantoins tested that were asymmetric at 5-C were racemic mixtures. Thus, if we assume that only one of the two phenyl groups is important in the displacement phenomenon, the displacement activity of monophenylated 5-C hydantoins ought to be half that of $\mathrm{DPH}$, but this is not the case. That 5,5-diphenylbarbituric acid is effective in displacing $T_{4}$ from TBG further shows the importance of the diphenyl linkage.

Clearly, factors besides these steric considerations must be important in the binding of $\mathrm{T}_{4}$ to TBG. First, the binding of DPH to TBG is very weak in comparison to that of $\mathrm{T}_{4}$ with this protein. The molar ratio of $\mathrm{DPH}$ concentration to the concentration of $\mathrm{T}_{4}$ displaced from $\mathrm{TBG}$ is 18,000 when $7.28 \times 10^{-4} \mathrm{M} \mathrm{DPH}$ is added to serum. The weakness of the binding, however, does not negate the relative specificity of DPH for the alpha globulin binding site. Second, diphenyl ether itself fails to displace $T_{4}$ from TBG. We believe that the hydantoin moiety plays an important role in anchoring the diphenyl linkage of DPH to the protein surface. The simultaneous substitution of both nitrogen groups of the hydantoin ring with methyl groups (Table IV) considerably diminishes the displacement activity of the resulting compound. Possibly, the simultaneous substitution of $1-\mathrm{N}$ and $3-\mathrm{N}$ prevents the enolization of the 2-C carbonyl group, which may supply a charged group for electrostatic attachment to the protein surface.

Both Larson and Albright (10) and Robbins and Rall (9) have investigated the displacement of $T_{4}$ from $T B G$ by a number of $T_{4}$ analogues and have failed to detect any displacement of $T_{4}$ when 3,5-diiodothyronine was added to serum. From this and other observations, they stressed the importance to the binding process of iodine substitution in the $3^{\prime}$ and $5^{\prime}$ positions of thyronine. The molar ratio, however, of diiodothyronine to $\mathrm{T}_{4}$ in both studies did not approach the ratio of $\mathrm{DPH}$ to $\mathrm{T}_{4}$ in the present investigation. Moreover, the demonstration by Wolff, Standaert, and Rall (3) that tetrachlorthyronine in low concentrations displaces $T_{4}$ from TBG also suggests that iodine may not be essential in binding to TBG. Robbins and Rall (9) also found that the compound formed by acetylating the amino and terminal hydroxyl group of $\mathrm{T}_{4}$ and methylating its carboxyl group,

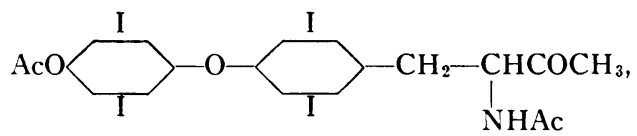

retains 34 per cent of the ability of the parent compound to bind to TBG. That such a compound, with all reactive groups blocked, can still bind substantially to TBG supports the suggestion that steric factors are important in the binding process.

\section{SUMMARY}

1. 5,5-Diphenylhydantoin (DPH) displaces $I^{131}$ thyroxine $\left(T_{4}\right)$ from its serum alpha globulin carrier. This effect can be reversed by dialyzing plasma containing DPH against saline for 48 hours. Furthermore, the same alpha globulin maximal binding capacity is attained by the addition of progressive increments of stable $\mathrm{T}_{4}$, both in the presence and in the absence of DPH. These findings indicate a competitive binding of $\mathrm{DPH}$ and $\mathrm{T}_{4}$ at the alpha globulin site.

2. Of 13 analogues of hydantoin tested that failed to displace $T_{4}-I^{131}$ from alpha globulin, none had a diphenyl substituent at 5-C of the hydantoin ring. Of 10 hydantoin analogues capable of dis- 
placing $\mathrm{T}_{4}-\mathrm{I}^{131}$ from alpha globulin, all but one possessed a diphenyl group at 5-C. The exception had one phenyl and one cyclohexene grouping at 5-C.

3. On the basis of the findings above and known interatomic distances and angles, we postulate that an analogy between $\mathrm{DPH}$ and $\mathrm{T}_{4}$ exists by virtue of the diphenyl linkage of $\mathrm{DPH}$ at $5-\mathrm{C}$ and the diphenyl ether linkage of $\mathrm{T}_{4}$, and suggest that both substances bind at a sterically complementary area on the receptor site.

\section{REFERENCES}

1. Oppenheimer, J. H., Fisher, L. V., Nelson, K. M., and Jailer, J. W. Depression of the serum protein-bound iodine level by diphenylhydantoin. J. clin. Endocr. 1961, 21, 252.

2. Oppenheimer, J. H., and Tavernetti, R. R. Studies on the thyroxine-diphenylhydantoin interaction: effect of 5,5-diphenylhydantoin on the displacement of L-thyroxine from thyroxine-binding globulin (TBG). Endocrinology 1962, 71, 496.

3. Wolff, J., Standaert, M. E., and Rall, J. E. Thyroxine displacement from serum proteins and depression of serum protein-bound iodine by certain drugs. J. clin. Invest. 1961, 40, 1373.
4. Sterling, K. and Tabachnick, M. Paper electrophoretic demonstration of thyroxine-binding prealbumin fraction in serum. Endocrinology 1961, 68, 1037.

5. Reinhold, J. G. Standard Methods of Clinical Chemistry, M. Reiner, Ed. New York, Academic Press, 1953, vol. 1, p. 88.

6. Sterling, K., and Tabachnick, M. Determination of the binding constants for the interaction of thyroxine and its analogues with human serum albumin. J. biol. Chem. 1961, 236, 2241.

7. Robbins, J., and Rall, J. E. The interaction of thyroid hormones and protein in biological fluids. Recent Progr. Hormone Res. 1957, 13, 161.

8. Tanaka, S., and Starr, P. Clinical observations on serum globulin thyroxine-binding capacity, using a simplified technique. J. clin. Endocr. 1959, $19,84$.

9. Robbins, J., and Rall, J. E. Effects of triiodothyronine and other thyroxine analogues on thyroxinebinding in human serum. J. clin. Invest. 1955, 34, 1331.

10. Larson, F. C., and Albright, E. C. The specificity of thyroxine binding by serum alpha globulin. Endocrinology 1955, 56, 737.

11. Robbins, J., and Rall, J. E. Proteins associated with the thyroid hormones. Physiol. Rev. 1960, 40, 415.

12. Tables of interatomic distances and configuration in molecules and ions. Special Bulletin 11. London, Chemical Society, 1958. 